九州大学学術情報リポジトリ

Kyushu University Institutional Repository

\title{
Some Properties of Pectinesterase from Rhizopus juponicus IF05318
}

\section{Elegado, Francisco $B$.}

BIOTECH, University of the Philippines

Katoh, Tatsuo

Department of Food Science and Technology, Faculty of Agriculture, Kyushu University

Fujio, Yusaku

Department of Food Science and Technology, Faculty of Agriculture, Kyushu University

https://doi.org/10.5109/24087

出版情報: 九州大学大学院農学研究院紀要. 40 (1/2), pp.1-8, 1995-12. Kyushu University バージョン：

権利関係: 


\title{
Some Properties of Pectinesterase from Rhizopus juponicus IF05318
}

\author{
Francisco B. Elegado*, Tatsuo Katoh and Yusaku Fujio \\ Department of Food Science and Technology, Faculty of Agriculture, \\ Kyushu University, Fukuoka 812-81, Japan \\ (Received April 19, 1995)
}

\begin{abstract}
A pectinesterase(PE) as a hydrolase was purified and partially characterized from pectinand cassava starch-supplemented wheat bran culture of Rhizopus japonicus IF05318, a strain selected among 25 isolates and authentic strains(from IFO). The PE was purified 162 folds with a recovery of $10.6 \%$ based on the total enzyme activity by batch extraction and column chromatography using SP-Sephadex C-50, CM-Sephadex C-50 and Sephadex G-75 gel filtration. The enzyme was stable at $\mathrm{pH}$ range of $5.0-8.5$ and up to $40^{\circ} \mathrm{C}$. The $\mathrm{pH}$ and temperature optima were 5.0 and $35^{\circ} \mathrm{C}$, respectively. The $\mathrm{K}_{\mathrm{m}}$ value was estimated as small value as $18.4 \mathrm{mg} / \mathrm{ml}$ from the Lineweaver-Burk plot, comparing reported fungal $K_{m}$ values. The molecular weight was determined as $33 \mathrm{kDa}$ by SDS-PAGE. The activity enhancers were $\mathrm{Cu}^{2+}, \mathrm{Ca}^{2+}, \mathrm{Na}^{+}$and $\mathrm{Mg}^{3+}$ while the inhibitors were $\mathrm{Pb}^{2+}, \mathrm{Ba}^{3+}, \mathrm{Zn}^{3+}, \mathrm{Fe}^{3+}$ and tannic acid.
\end{abstract}

\section{INTRODUCTION}

To convert farming products to more valuable one, Rhizopus strains have been isolated from fermented foods and other sources in order to saccharify straight cassava tuber or starch. As a first step, enzyme production by the Rhizopus isolates and some IFO authentic Rhizopus strains were tested on amylase, pectolytic enzymes, proteolytic enzymes and cellulolytic enzymes. Among of the extracellular hydrolytic enzymes, pectolytic enzymes are classified into several forms, namely the polygaracturonases, the pectinesterases and pectin lyases(Deuel and Stiltz, 1958). Studies concerning the purification of pectic enzymes of strains mostly dealt with polygaracturonase(PG) (Trescott and Tampion, 1974; Liu and Luh, 1987; Lee and West, 1981; Manachini et al., 1987) in Rhixopus sp.(Archer, 1979), no purification work on PE has been done yet. Previously, we made some purification and characterization studies on polygaracturonase (Lourrungrung et al., 1993) from Rhizopus japonicus IF05318. From an enzyme screening work from Rhixopus isolates and IFO authentic strains, we found out that Rhizopus japonicus IF05318 was the most potent PE producer on solid wheat bran medium from jamong our isolates and authentic strains.

Present work deals with the purification and partial characterization of PE from Rhizopus japonicus IF05318 as a hydrolase because there has been no characterization work of the PE yet.

\footnotetext{
* BIOTECH, University of the Philippines at Los Banos, Laguna, Philippines
} 


\section{MATERIALS AND METHODS}

\section{Microorganisms and culture medium}

Twenty five Rhizopus isolates and IFOstrains were used for the screening work. They were maintained on potato dextrose agar(PDA) slants, making fresh culture every 3 months.

\section{Cultivation}

The flask cultures were macerated with five-folds of $0.05 \mathrm{M}$ acetate buffer( $\mathrm{pH} 5.0)$ and the enzyme was extracted for overnight at $4^{\circ} \mathrm{C}$. Then, the crude enzyme extract was obtained by squeezing, vacuum filtration through Celite bed pre-coated on Toyo No. 2 filter paper and centrifugation at $15,000 \mathrm{X} \mathrm{g}$ for $20 \mathrm{~min}$.

\section{PE purification}

All purification steps were done at $4^{\circ} \mathrm{C}$. PE was first extracted from the crude enzyme solution by batch treatment with SP-Sephadex C-50 at $\mathrm{pH} 5.0$. The $\mathrm{pH}$ of the crude enzyme(2l) was adjusted to pH 5.0 with 2-N acetic acid and SP-Sephadex C-50(5g, pre-swollen in $0.05 \mathrm{M}$ acetate $\operatorname{buffer}(\mathrm{pH} 6.0)$ was added. The mixture was stirred for $2 \mathrm{~h}$, then filtered and the residue was repeatedly washed with the same acetate buffer. The $\mathrm{PE}$ and other proteins, selectively adsorbed on to SP-Sephadex C-50, was eluted by mixing with $500 \mathrm{ml}$ of $0.5 \mathrm{M} \mathrm{NaCl}$ dissolved in the same buffer, and filtered through Toyo No. 7 filter paper. Then the filtrate was dialyzed against the same acetate buffer for overnight. The dialyzate $(680 \mathrm{ml})$ was vacuum filtered through $0.02 \mu \mathrm{m}$ millipore filter and applied on to SP-Sephadex C-50 column chromatography $(2.5 \mathrm{X} 38 \mathrm{~cm})$, pre-equilibrated with the same acetate buffer. The column was eluted with a linear gradient of $0-0.3 \mathrm{M}$ $\mathrm{NaCl}$ in similar buffer at a flow rate of $30 \mathrm{ml} / \mathrm{h}$. The major active fractions were pooled, dialyzed against $0.05 \mathrm{M}$ acetate buffer $(\mathrm{pH} 6.0)$ for overnight and concentrated by ultrafiltration through a membrane with molecular cut-off of $10 \mathrm{kDa}$ with nitrogen pressurization at $3 \mathrm{~kg} / \mathrm{cm}^{2}$. The enzyme concentrate $(20 \mathrm{ml})$ was charged next to $\mathrm{CM}$ Sephadex C-50 column chromatography $(2.5 \times 38 \mathrm{~cm})$, pre-equilibrated with $0.05 \mathrm{M}$ acetate buffer( $\mathrm{pH} 6.0)$. Elution was done using a linear gradient of $0-0.3 \mathrm{M} \mathrm{NaCl}$ dissolved in the same acetate buffer at a flow rate of $20 \mathrm{ml} / \mathrm{h}$. The PE active fractions were pooled, concentrated by ultrafiltration (10ml) and applied on to Sephadex G-75 gel filtration at a flow rate of $4.5 \mathrm{ml} / \mathrm{h}$ and $3 \mathrm{ml}$ fractions were collected. Finally, the fractions having the protein peak that coincided with the PE activity, freed from PG activity, was collected and concentrated by ultrafiltration $(6 \mathrm{ml})$ as the purified enzyme.

\section{Enzyme activity assays}

PE activity assay was based on the release of methanol from pectin. The reaction mixture, composed of $4 \mathrm{ml}$ of $1 \%$ pectin and $0.1 \mathrm{ml}$ of enzyme solution was incubated at $35^{\circ} \mathrm{C}$ for $15 \mathrm{~min}$. The reaction was stopped by addition of $0.5 \mathrm{ml} 2-\mathrm{N} \mathrm{H}_{2} \mathrm{SO}_{4}$ and the methanol released was estimated by the method of Wood and Siddiqui(Wood and Siddiqui, 1971). One unit of PE was expressed as one micro mole methanol liberated per min-ml-enzyme solution. PG activity was assayed based on the release of garacturonic acid from pectic acid estimated using the dinitrosalicytic acid(DNS) method for reducing 
sugar determination against alpha-galacturonic acid as a standard(Miller, 1959). A $0.9 \mathrm{ml}$ of $1 \%$ pectic acid solution (dissolved in O.lM acetate buffer to make $\mathrm{pH} 4.5$ ) was reacted with $\mathrm{O} . \mathrm{lml}$ of the enzyme solution at $40^{\circ} \mathrm{C}$ for $15 \mathrm{~min}$. One unit of enzyme activity was expressed as one micro-mole galacturonic acid liberated per min-ml of enzyme solution.

\section{Protein determination}

The protein content was estimated by reading the absorbance at $280 \mathrm{~nm}$ or by using the method by Lowry et al., as modified by Hartree(1972), against bovine serum albumin as a standard.

\section{Electrophoresis}

SDS-PAGE was performed using $12.5 \%$ polyacrylamide gel and Tris-glycine buffer(pH 8.4), according to the discontinuous buffer system method of King and Laemmli(1971). The gels were stained with $0.1 \%$ Coomassie brilliant blue R-250 and destained in $7.5 \%$ acetic acid.

\section{Temperature and pH dependencies}

The effect of temperature and $\mathrm{pH}$ activity was determined by varying the $\mathrm{pHs}$ and temperatures of activity assay. Thermo-stability and $\mathrm{pH}$ stability were determined by assaying the remaining activity after incubating at various temperature for $60 \mathrm{~min}$ or various $\mathrm{pHs}$ for $24 \mathrm{~h}$ at $4^{\circ} \mathrm{C}$. The buffers used were $0.05 \mathrm{M}$ of Clark and Lubs buffer(pH 1-2 and 8-10), McIlvane buffer ( $\mathrm{pH}$ 3-7.5) and $\mathrm{Na}_{3} \mathrm{CO}_{3}-\mathrm{NaHCO}_{3}$ buffer(pH 11-12).

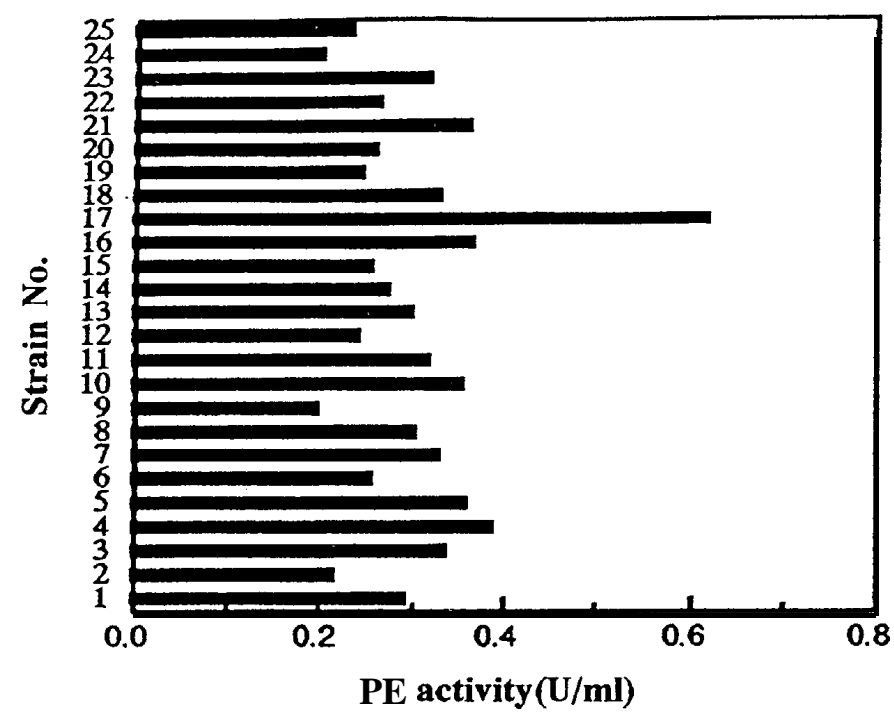

Fig. 1. PE activity assay of the wheat bran culture extract of 25 Rhizopus strains. 


\section{RESULTS AND DISCUSSION \\ Screening for best PE producing strain}

Figure 1 shows the results of PE activity of the crude enzyme extracts of the strains grown on pectin and cassava starch supplemented wheat bran medium. Rhixopus japonicus IF053 18 gave the highest PE activity of $0.64 \mathrm{U} / \mathrm{ml}$ of crude enzyme extract, about twice as much as that of other strains.

Table 1. Summary of purification of PE from Rhizopus japonicus IF05318.

\begin{tabular}{lcccrrrr}
\hline $\begin{array}{l}\text { Purification } \\
\text { step }\end{array}$ & $\begin{array}{c}\text { Volume } \\
(\mathrm{ml})\end{array}$ & $\begin{array}{c}\text { PE } \\
\text { activity } \\
(\mathrm{U} / \mathrm{ml})\end{array}$ & $\begin{array}{c}\text { Total } \\
\text { activity } \\
(\mathrm{U})\end{array}$ & $\begin{array}{c}\text { Protein } \\
(\mathrm{U} / \mathrm{mg})\end{array}$ & $\begin{array}{c}\text { Specific } \\
\text { activity } \\
(\mathrm{U} / \mathrm{ml})\end{array}$ & $\begin{array}{c}\text { Recovery } \\
(\%)\end{array}$ & $\begin{array}{c}\text { Purification } \\
\text { folds }\end{array}$ \\
\hline Crude enzyme & 2,000 & 0.37 & 740 & 0.62 & 0.60 & 100 & 1.0 \\
\hline $\begin{array}{l}\text { SP Sephadex } \\
\text { C-50(batch) }\end{array}$ & 680 & 0.71 & 480 & 0.80 & 0.89 & 65 & 1.5 \\
\hline $\begin{array}{l}\text { SP Sephadex } \\
\text { C-50(column) }\end{array}$ & 20 & 17.0 & 340 & 0.27 & 6.27 & 46 & 10.5 \\
\hline $\begin{array}{l}\text { CM Sephadex } \\
\text { C-50(column) }\end{array}$ & 10 & 16.0 & 160 & 0.47 & 33.8 & 22 & 56.3 \\
$\begin{array}{l}\text { Sephadex G-75 } \\
\text { gel filtration }\end{array}$ & 6 & 13.0 & 78 & 0.13 & 97.0 & 10.6 & 162.0 \\
\hline
\end{tabular}

\section{PE purification}

Table 1 shows the summary of the four chromatography steps done purified the enzyme by 162 folds and a recovery of $10.6 \%$ was obtained on the enzyme activity. Batch

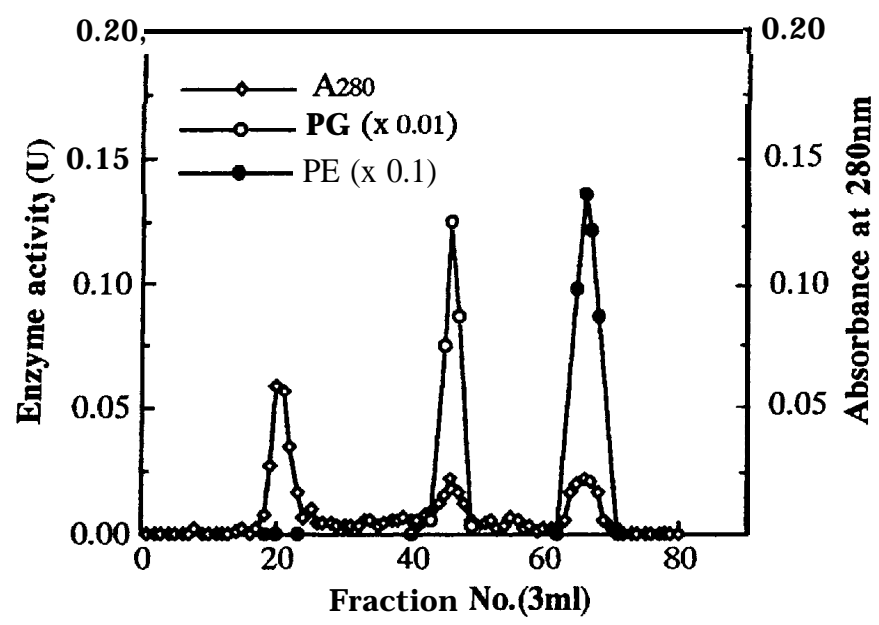

Fig. 2.

The enzyme was eluted with $0.05 \mathrm{M}$ phosphate buffer $(\mathrm{pH} \mathrm{7.5)} \mathrm{at}$ a flow rate of $4.5 \mathrm{~m} / \mathrm{h}$. 
extraction using SP-Sephadex C-50 adsorbed most of the PE and 65\% was recovered upon elution with $0.5 \mathrm{M} \mathrm{NaCl}$. On the other hand, about $20 \%$ of the PG activity was retained. After SP-Sephadex C-50 chromatography, the major PE activity peak was separated from the major peaks by the conditions set in the column chromatography, although some minor PG activities remained. Further separation of the PE from the

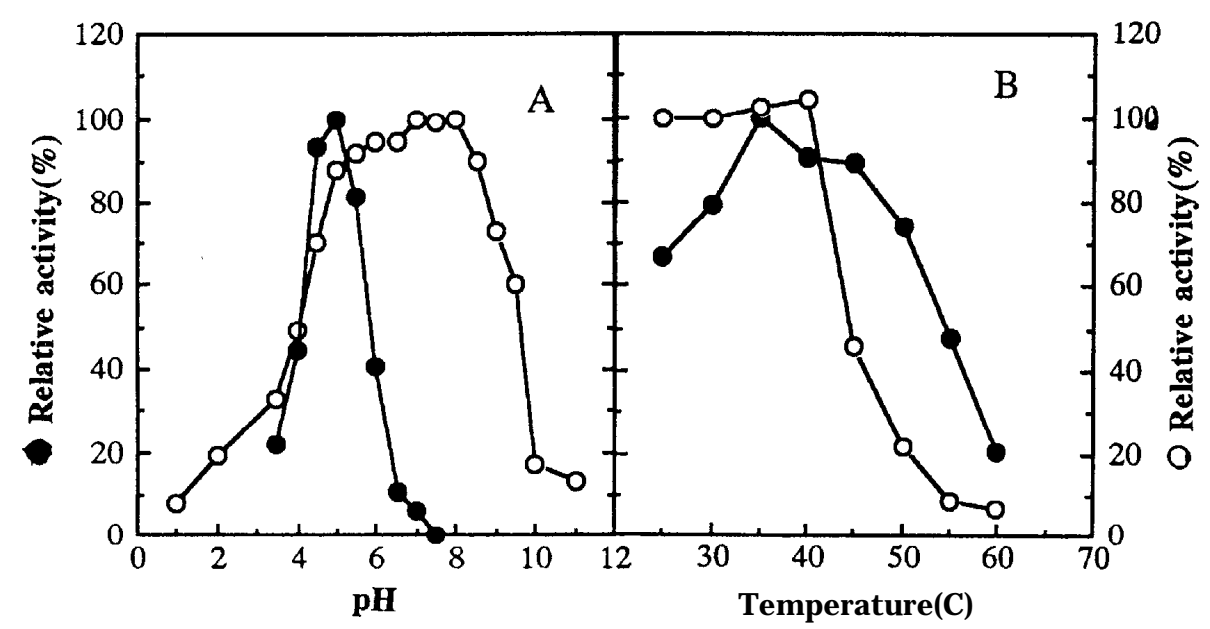

Fig. 3. $\mathrm{pH}$ and temperature optima (O)and stability (O) of Rhizopus japonicus IFO5318PE. The enzyme was incubated in various buffers for $24 \mathrm{~h}$ at $4^{\circ} \mathrm{C}$ for $\mathrm{pH}$ stability determination and in desired temperature for $60 \mathrm{~min}$ at $\mathrm{pH} 7.5$ for temperature stability determination.

contaminating PG was made possible through chromatography in CM-Sephadex C-50 column. Figure 2 shows the result of Sephadex G-75 gel filtration that the PE activity coincided to a single peak, freed from the PG active fraction.

\section{Effect of pH and temperature}

Figure 3-A shows the effect of $\mathrm{pH}$ on the activity of the present PE. The enzyme was stable at $\mathrm{pH} 5-8.5$ after incubation at $4^{\circ} \mathrm{C}$ while the optimum $\mathrm{pH}$ of the activity was $\mathrm{pH}$ 5.0. The $\mathrm{pH}$ optimum is typical of previously reported fungal PEs although $\mathrm{pH}$ stability was wider compared to Aspergillus japonicus PE(Ishii et al., 1979) and Coniothyrium diplodiella $\mathrm{PE}($ Endo, 1964) but narrower than that of Aspergillus oryzae PE(Lim et al., 1983) and Corticium rolfsii(Yoshida et al., 1977). Figure 3-B shows the effect of temperature on the activity and stability of the present PE. The optimum temperature for the reaction was $35^{\circ} \mathrm{C}$ and rapid inactivation occurred upon incubation at temperature above $40^{\circ} \mathrm{C}$ for $60 \mathrm{~min}$. Such temperature characteristics are slightly inferior compared to that of most fungal PEs.

\section{$\mathbf{K}_{\mathrm{m}}$ value}

Figure 4 shows Lineweaver-Burk plot of the PE and the K,,, value was determined as $18.4 \mathrm{mg} / \mathrm{ml}$. This value is only one third compared to the reoprted $\mathrm{K}_{\mathrm{m}}$ value for the PE-II 


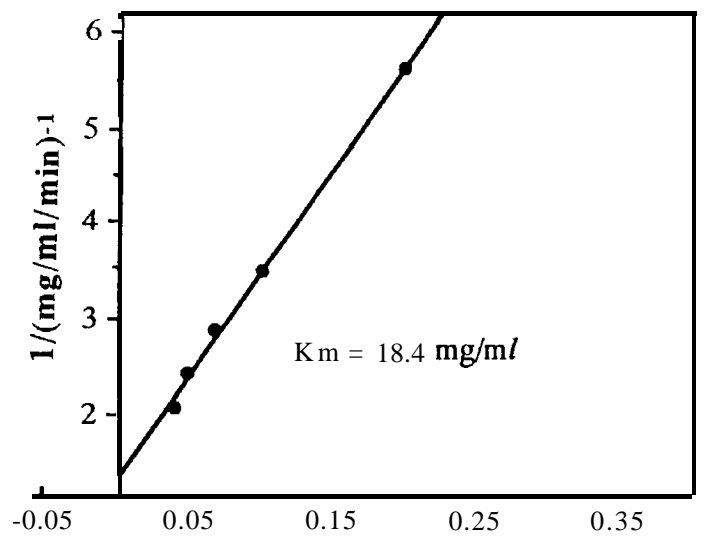

Fig. 4. Determination of $K_{m}$ value by the Lineweaver-Burk plot.

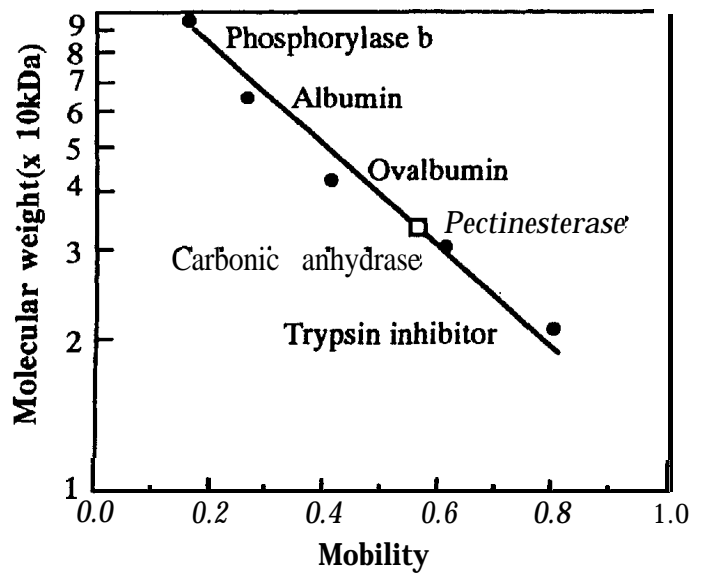

Fig. 5. Determination of the molecular weight of PE from Rhizopus japonicus IF05318.

of Aspergillus oryzae which was $50 \mathrm{mg} / \mathrm{ml}$ (Lim et al., 1983). The $\mathrm{K}_{\mathrm{m}}$ value of the present $\mathrm{PE}$ was so small that the hydrolysis rate of pectin substance by the PE can be more suitable enzyme than that of reported fungalPEs.

\section{Molecular weight}

Figure 5 shows logarithmic plot of the SDS-PAGE results using low molecular weight standard marker protein(BIO-RAD) and the molecular weight of the present PE was estimated $33 \mathrm{kDa}$. The value is quite comparable to the molecular weight of Aspergillus oryzae $\mathrm{PE}(\mathrm{Lim}$ et al., 1983) and Aspergillus juponicus PE(Endo. 1964). 
Table 2. Effect of ionic compounds, phenolic compounds and inhibitors on the activity of PE.

\begin{tabular}{lccclc}
\hline Compounds Relative activity & \multicolumn{2}{c}{ Compounds Relat ivr activity Compounds } & Relative activity \\
\hline control & 100 & CuSO & 156 & EDTA & 114 \\
$\mathrm{KCl}$ & 84 & $\mathrm{CaCl}_{2}$ & 144 & PMSF & 100 \\
$\mathrm{NaCl}$ & 127 & $\mathrm{BaCl}_{3}$ & 79 & Gallic acid & 98 \\
$\mathrm{NiCl}_{2}$ & 104 & $\mathrm{MgCl}_{3}$ & 12.5 & Tannic acid & 52 \\
$\mathrm{LiCl}_{2}$ & 112 & $\mathrm{MnSO}_{1}$ & 114 & p-Coumaric acid & 90 \\
$\mathrm{ZnSO}$ & 75 & $\mathrm{AlCl}_{3}$ & 93 & Chlorogenic acid & 121 \\
$\mathrm{~Pb}(\mathrm{CHCOO})_{2}$ & 51 & $\mathrm{Fe}_{3}\left(\mathrm{SO}_{3}\right)$ & 72 & Cnffeic acid & 98
\end{tabular}

\section{Effect of cations, phenolic compounds and inhibitors}

Table 2 shows the effect of some ionic, phenolic and protein inhibitory compounds at a concentration of $1 \mathrm{mM}$ on the PEs activity. Some cations enhanced the activity to as much as $20-50 \%$, particularly $\mathrm{Cu}^{+*}, \mathrm{Ca}^{3+}, \mathrm{Na}^{+}$and $\mathrm{Mg}^{2+}$. On the other hand, the heavy metallic ions, $\mathrm{Pb}^{2+}, \mathrm{Fe}^{2+}, \mathrm{Zn}^{2+}$ and $\mathrm{Ba}^{2+}$ and tannic acid inhibited the activity from $30-50 \%$. EDTA and PMSF did not cause any significant effect on the PE activity. The enhancers and inhibitors of Rhizopus japonicus IF05318 PE have almost similar actions as to that of other fungalPEs, except that of $\mathrm{Cu}^{ \pm-}$which activates the present PE but inhibits Aspergillus oryzae $\mathrm{PE}$ (Lim et al., 1983). In general, $\mathrm{CaCl}_{2}$ and $\mathrm{NaCl}$ caused the most pronounced enhancement of most fungal PE activities. Tannic acid is a noted inhibitor of pectic enzymes(Liu and Luh, 1978) because of its high molecular weight. The mechanism of inhibition seems to be largely dependent on the random blocking of the active site by the large molecular sizes of the inhibitors.

\section{REFERENCES}

Archer, S. A. 1979 Chemical and nutritional characterization of lupine tempeh. J.Sci.in Foodand Agr., 30: $692-703$

Dueal, H. and E. Stultz 1958 Pectic enzymes. Adrancesin Enzymology, 20: 341-382

Endo, A . 1964 Studies on pe ctoly i c Agrisiol.Chem, f28m757t764 P a r t

Hartree, E. F. 1972 Determination of protein: a modification of the Lowry method that gives a linear photometric response. Analyt. Biochem., 48: 422-427

Ishii, S., K. Kiho, S. Sugiyama and H. Sugimoto 1979 Low-methoxy pectin prepared by pectinesterase from Aspergillus japonicus. J. Food Sci, 44: 611-614

King, J. and U. K. Laemmli 1971 Polypeptides of the tail fibres of bacteriophage T4. J.Molecular Biol., 62: $465-477$

Lee, S. C. and C. A. West 1981 Properties of Rhizopus stolonifer polygaracturonase, and elicitor of cnsbene synthease activity in castor bean (Ricinus communis L.) seedings. Plant Physiol., 67: 640645

Lim, J. Y., Y. Fujio and S. Ueda 1983 Purification and characterization of pectinesterase and pectin lyase from Aspergillus oryzae A-3. J. Appl. Biochem., 5: 91-98

Liu, Y. K. and B. S. Luh 1978 Purification and characterization of endo-polygaracturonase from Rhizopus arhizus. J.Food Sci., 43: 72 1-726

Lourrungruang, C. and Y. Fujio 1992 Purification and characterization of polygaracturonase from Rhizopus japonicus IFO5318. ICBiotech, 15: 31 1-319

Manachin, P. L., M. G. Fortuna and C. Parini 1987 Purification and properties of an endo- 
polygaracturonase produced by Rhizopus stolonifer. BiotechnologyLetters, 9: 219-224

Miller, G. L. 1959 Use of dinitrosalicylic acid reagent for determination of reducing sugar. Analyt.Chem., 39: $426-428$

Trescott, A. S. and J. Tampion 1974 Properties of endopolygaracturonase secreted by Rhizopus stolonifer. J. Gen. Microbiol., 80:401-409

Wood, P. J. and I. R. Siddiqui 1971 Determination of methanol and its application to measurement of pectin ester content and pectin metyl esterase activity. Analyt.Biochem., 39: 418-428

Yoshihara, O., T. Matsuo and A. Kaji 1977 Purification and properties of acid pectinesterase from Corticiurn rolssii. Agr. Biol.Chem., 41: 2335-2341 